\title{
A MÍDIA NO BANCO DOS RÉUS: CONSIDERAÇÕES SOBRE MAGISTRADOS, DESENVOLVIMENTO, DIGNIDADE E MORALIDADE A PARTIR DE PROPAGANDAS DE CERVEJA
}

\author{
Leilane Serratine Grubba ${ }^{1}$ \\ Amanda Muniz Oliveira ${ }^{2}$
}

\section{Resumo}

O presente ensaio tem como tema a mídia, o Poder Judiciário, a dignidade e a moral, e procura demonstrar a necessidade de se repensar o papel dos juízes como guardiões morais das demandas jurídicas e sociais. Tendo como ponto de partida o dogma criticado por Jeremy Waldron, de que os juízes seriam os indivíduos mais indicados para resolver questões moralmente controversas, nos voltaremos a duas decisões judiciais relativas a casos semelhantes: propagandas de cerveja com potencial ofensivo à dignidade feminina. O objetivo principal é problematizar as questões oriundas do dogma mencionado. Para tanto, metodologicamente, será analisado o papel da mídia e de sua linguagem para, após, questionar a ideia de que o Poder Judiciário está apto a deliberar moralmente sobre questões controversas. Por fim, levanta-se a problemática do envolvimento da moralidade individual em questões jurídicas relativas aos Direitos Humanos.

Palavras-chave: Direito; Mídia; Poder Judiciário; Moral; Dignidade Feminina.

\section{INTRODUÇÃO}

O dogma de que os juízes apresentam habilidades superiores para tratar de questões relativas ao Direito e à moralidade é oferecido e criticado por Jeremy Waldron (2009, p. 2-24). Segundo tal dogma, o raciocínio moral dos juízes, em questões controvertidas, seria melhor que o raciocínio possivelmente oferecido pelo Legislativo, de forma que o Poder Judiciário estaria apto a portar-se como autoridade final no que se refere a temas polêmicos.

Adotando o referido dogma como ponto de partida, o presente ensaio busca analisar um caso julgado pelo judiciário brasileiro no ano de 2016, no qual a liberdade de expressão e a dignidade humana ${ }^{3}$ foram

\footnotetext{
${ }^{1}$ Doutora em Direito pela Universidade Federal de Santa Catarina. Professora do Programa de Pós-Graduação Stricto Sensu em Direito da Faculdade Meridional. Professora dos Programas de Pós-Graduação Lato Sensu da Faculdade Meridional e Universidade Nove de Julho. Professora dos Cursos de Direito da Faculdade Meridional e Faculdade CESUSC. Professora da Escola Superior do Ministério Público de Santa Catarina. Pesquisadora da Fundação Meridional. E-mail: lsgrubba@hotmail.com

${ }^{2}$ Doutoranda em Direito pela Universidade Federal de Santa Catarina. Pesquisadora do Núcleo de Estudos Conhecer Direito NECODI - UFSC. E-mail: amandai040@gmail.com

${ }^{3}$ A dignidade humana, afirma Leal (2015, p. 35-36), é uma qualidade inseparável do ser humano, um princípio absoluto, central e inviolável, do qual emanam todos os demais princípios do ser humano e dos direitos humanos.
} 
polarizadas e debatidas: o caso da condenação da Companhia de Bebidas das Américas - Ambev -, em razão de uma propaganda veiculada pela cerveja Skol.

O caso em questão suscita três pontos principais: o primeiro refere-se ao papel das mídias no cotidiano; o segundo trata da utilização do Direito para vetar certos discursos, compreendidos como moralmente inadequados; o terceiro refere-se à vinculação de decisões morais no que tange à proteção de direitos positivados, como questões que envolvem Direitos Humanos. Desta forma, o objetivo principal da pesquisa é problematizar os enigmas oriundos do dogma que Waldron irá chamar de JGM - judges are good at morality.

Ainda que determinados movimentos sociais, a exemplo do movimento feminista, celebrem decisões como a mencionada de 2016, a hipótese oferecida sugere a necessidade de atenção às consequências de se entregar aos magistrados o poder absoluto de dizer o que é ou não moralmente aceitável e, mais do que isso, o problema da vinculação de discursos morais no que tange a direitos certos, como os Direitos Humanos.

Metodologicamente, faremos algumas considerações a respeito da mídia, isto é, meio de comunicação de massa, no intuito de demonstrar a complexidade deste tipo de linguagem; em seguida, questionaremos a ideia de que os juízes são os indivíduos mais indicados a deliberarem moralmente sobre questões controversas, tendo como exemplo outro comercial de cerveja, veiculado pela Schincariol, referente à questão de gênero e racial. Desta forma, procuraremos demonstrar a relevância das observações de Waldron e a necessidade de se repensar o papel dos magistrados como guardiões da moralidade.

\section{MÍDIA, DIREITO E SOCIEDADE EM COMERCIAIS DE CERVEJA}

A cena é corriqueira: geralmente há um bar, sorrisos, moças 'esteticamente' 'bonitas' e homens empolgados. Quando ela - a cerveja - é servida, algo cômico ocorre, atrelando-se o produto à felicidade de quem o consome. Geralmente, os comerciais de cerveja recorrem a este clichê genérico, ora enfatizando o humor, ora evidenciando os atributos físicos do gênero feminino.

Esse foi o caso de um comercial veiculado pela Companhia de Bebidas das Américas - Ambev -, que por focar na suposta beleza feminina como forma de merchandising, isto é, pela divulgação da peça publicitária Musa do Verão, veiculada em rede nacional no ano de 2006, foi condenada pela 7a Câmara de Direito Público de São Paulo ao pagamento de multa no valor de $\mathrm{R} \$ 305$ mil reais.

Resumidamente, o caso posto em julgamento, referente ao comercial, veiculou uma propaganda que retratou um concurso de beleza feito à beira mar. No enredo da narrativa, um consumidor de cerveja afirma que, se o criador da cerveja Skol também tivesse criado a Musa do Verão, ela seria acessível a todos os homens. Logo, em um devaneio, ele imagina uma fábrica de clones replicando a bela musa e vendendo estes clones para diversos homens, de diversas idades. 
O caso retratado será utilizado como fonte midiática para a análise do dogma explicado e criticado por Jeremy Waldron, de que os juízes estão aptos a decidirem questões que concernem à moralidade. Mas antes que seja possível prosseguirmos, é necessário explicar o que é a mídia e qual o papel social que ela possui hoje em dia.

Aparentemente, o mundo ocidental hegemônico hoje vive na era das imagens, motivo pelo qual parece certo assumir que a população, em geral, sabe o que são as mídias. Em larga medida, grande parte da população mundial nasceu após a era das imagens digitais. Da seleção de músicas no celular; dos quadrinhos expostos na banca de revista; dos jogos online (em celular, no computador, etc.); do outdoor de propaganda nas ruas; dos aguardados lançamentos hollywoodianos no cinema mais próximo; às últimas notícias no jornal televisivo, vive-se na era midiática; apesar de boa parte da população mundial não conseguir interpretá-la. Hoje em dia, parece fácil conhecer um país ou cidade distante, sem que haja a necessidade de locomoção; basta acessar a internet. De fato, toda essa gama de aparatos comunicativos pode ser agrupada por uma simples palavra de cinco letras: mídia. Mídias são meios de comunicação de massa.

Endemonizada quando parcial e sacralizada quando imbuída de representatividade, a mídia, mais do que nunca, divide opiniões e gera acirrados debates, tanto no cotidiano quanto teoricamente. Theodor Adorno, um dos primeiros pesquisadores a apontar seus malefícios, criou um termo próprio para caracterizá-la: Indústria Cultural (ADORNO; HORKHEIMER, 1985, p. 99-138).

Marcada pela massificação das obras de arte, com o objetivo único de auferir lucro das diversas audiências, a mídia é vista como alienadora pelo pensador da chamada Escola de Frankfurt ${ }^{4}$, Adorno, que irá teorizar e problematizar os discursos midiáticos, desde a desvalorização de obras de arte clássicas à bestialização das audiências por parte da Indústria Cultural.

Adorno foi timidamente contrariado pelo seu então bolsista ${ }^{5}$, Walter Benjamin (1987, p. 17), para quem a perda da aura da obra de arte ${ }^{6}$, com o advento das mídias, seria algo positivo. Para ele, a mídias tornavam os conteúdos artísticos mais acessíveis ao público em geral e, ainda, fazem com que a arte possa ser consumida enquanto distração. Adorno, ao fim da vida, irá rever suas atitudes, percebendo empiricamente que o público não é tão alienado como ele próprio pensava, chegando por vezes a duvidar das informações veiculadas pela mídia?

\footnotetext{
${ }^{4} \mathrm{O}$ Instituto de Pesquisa Social, vinculado à Universidade de Frankfurt, mais tarde conhecido como Escola de Frankfurt, era um espaço no qual diversos autores, como Theodor Adorno, Max Horkheimer, Erich Fromm, Herbert Marcuse e Walter Benjamin, dentre muitos outros, procuravam compreender o desenvolvimento das sociedades capitalistas no século XX, a partir de um paradigma marxista. Em razão de sua abordagem interdisciplinar, assuntos diversos foram abordados como política, movimentos sociais, economia, direito e manifestações culturais.

${ }^{5}$ Conforme Marcos Napolitano (2005, p.24), Walter Benjamin era bolsista no Instituto de Pesquisas Sociais de Frankfurt e dependia dos pareceres de Adorno para continuar a receber o benefício.

${ }^{6}$ A aura seria o caráter sacro responsável pela atitude reverencial do público em relação à obra de arte até então. A perda dessa característica teria auxiliado no maior acesso a tais bens. (BENJAMIN, 1987, p. 165-196).

${ }^{7}$ Em síntese, a mídia estava veiculando incessantemente o casamento de monarcas holandeses como o acontecimento político do século. Adorno realiza um questionário com telespectadores diversos, perguntando-lhes sobre a importância política do evento e é
} 
Mas é o filósofo americano Douglas Kellner que irá propor uma nova abordagem do produto midiático, desmistificando preconceitos e levantando questões antes não abordadas:

Há uma cultura veiculada pela mídia cujas imagens, sons e espetáculos ajudam a urdir o tecido da vida cotidiana, dominando o tempo de lazer, modelando opiniões políticas e comportamentos sociais, e fornecendo o material com que as pessoas forjam sua identidade. $\mathrm{O}$ rádio, a televisão, o cinema e os outros produtos da indústria cultural fornecem os modelos daquilo que significa ser homem ou mulher, bem-sucedido ou fracassado, poderoso ou impotente (KELLNER, 2001, p. 9).

Trata-se de pensar a recepção da mídia pelo público. Kellner (2001, p. 105-107) sugere que os textos midiáticos geram uma multiplicidade de efeitos nas pessoas, mas atenta para os ídolos que se tornam imagens ressonantes e referenciais para o público. Segundo o pensador, são as imagens que conseguem levar o público a imitá-las, tanto nas vestimentas, como nos comportamentos e opiniões, inclusive nos preconceitos e na criação de papeis sociais.

Mais do que isso, Kellner (2001, p. 105-107) atenta para as cenas paleossimbólicas, que são aquelas capazes de afetar a percepção do público, naturalizando comportamentos. Como exemplo, o autor menciona as representações de cenas de preconceito racial ou de violência contra a mulher, que podem naturalizar comportamentos e influenciar que tais atitudes sejam cometidas.

Assim, parece que os diversos pontos de vista sociais (os papeis sociais) que circulam na sociedade sofrerão influência direta das veiculações midiáticas, seja para ratificá-los ou retificá-los. A típica donzela em perigo, o herói disposto a enfrentar o mundo, o intelectual reservado que fracassa no amor, o advogado corrupto e a miss como modelo ideal de mulher, que pode inclusive ser comprada, mais do que personagens inocentes e despretensiosos, aparecem como estereótipos naturais, naturalizando e reforçando comportamentos padrões desejáveis de acordo com determinados padrões culturais.

Esses papéis sociais polarizadores impostos midiaticamente por padrões culturais se adequam às denominadas imagens canônicas, retratadas pelo historiador Elias Thomé Saliba como:

[...] imagens padrão ligadas a conceitos chaves de nossa vida social e intelectual. Tais imagens constituem pontos de referência inconscientes sendo, portanto, decisivas em seus efeitos subliminares de identificação coletiva. São imagens de tal forma incorporadas em nosso imaginário coletivo, que as identificamos rapidamente (2007, p. 88).

Assim, a veiculação midiática de uma propaganda na qual a mulher ideal, no que tange ao padrão cultural de beleza imposto esteticamente, pode ser comprada, reforça-se a ideia da mulher que segue os padrões de beleza vigentes como um produto a ser consumido pelo masculino. Esta foi a impressão que teve o juiz Luiz Sérgio Fernandes de Souza, relator do processo sob análise nesta pesquisa:

O argumento da peça publicitária é mais do que infeliz, pois "coisifica" a mulher, servindo-a, mediante entrega, para desfrute do consumidor. Em outras palavras, nela, o gênero feminino

surpreendido quando o resultado da pesquisa mostra que a maioria dos entrevistados não encarava o ocorrido como tal, mas como mera trivialidade. (ADORNO, 2002, p. 103-116). 
transforma-se em objeto de consumo. Alguém poderia dizer que se trata apenas de um "clone" de mulher, e não de uma mulher de carne e osso. Mas as propagandas nunca são feitas de pessoas de carne e osso, pelo que o argumento cede diante do poder de sugestão que o marketing exerce. Tampouco se venha dizer, como afirma a autora, que apenas grupos feministas se mostraram escandalizados com a campanha "Musa do Verão". O que importa é que nela há discriminação do sexo feminino, a justificar a lavratura do auto de infração e a imposição de multa, com fundamento na regra do artigo 37, $\$ 2^{\circ}$, do Código de Defesa do Consumidor. A luta pelo espaço igualitário da mulher na sociedade é tema que ganha cada vez mais força no mundo. No momento em que a sociedade busca proscrever a ideia de que o gênero feminino é mero objeto de prazer, não se pode legitimamente sustentar que a valorização da mulher seja vista apenas como uma bandeira de determinado setor (radical) da sociedade. Todos estão envolvidos com a superação de estereótipos grosseiros, lugar comum sempre presente quando o assunto é publicidade ${ }^{8}$.

O juiz ainda sugere que propagandas nas quais mulheres casadas apanhavam dos maridos eram comuns ainda na segunda metade do século XX - o que naturalizava a questão da violência doméstica e do papel social da mulher submissa.

O relatório do processo, no caso em análise, não retrata uma decisão moral do juiz, mas uma perfeita vinculação ao texto expresso da Convenção sobre a Eliminação de todas as formas de Discriminação contra as Mulheres (CEDAW), adotada pelas Nações Unidas na resolução 34/1980, de dezembro de 1979. Segundo o texto da Convenção, os Estados-parte, inclusive o Brasil, estão obrigados a eliminar dos seus territórios nacionais os preconceitos e práticas baseados na ideia de inferioridade ou superioridade de gênero, pois considera-se que os costumes, as normas e os estereótipos que dão origem ao grande número de restrições legais, políticas e econômicas sobre o avanço do desenvolvimento das mulheres (NAÇÕES UNIDAS, 1979).

Dessa forma, do texto da CEDAW se extrai a necessidade de o Brasil condenar a discriminação contra a mulher, em todas as suas formas, e agir por todos os meios apropriados a eliminar a discriminação fundada no gênero, inclusive por meio do Poder Judiciário (NAÇÕES UNIDAS, 1979). Nesse sentido, parece acertada a decisão do juiz que condenou a discriminação feminina veiculada no comercial televisivo, considerando que a mulher não é mero objeto de prazer e deve ser tratada em igualdade com os homens, para a superação dos estereótipos nocivos socialmente.

Além disso, que a mulher não pode ser objetificada e consumida ou comprada pelos homens, sendo sua propriedade. A mulher, pelo contrário, é um ser humano livre e possuidor de dignidade e direitos inalienáveis (GRUBBA, 2015).

A argumentação destacada foi compartilhada pelo juiz revisor do processo, Moacir Peres, para quem:

No caso dos autos, a propaganda de cerveja utiliza-se da figura de uma mulher para enaltecer a qualidade do seu produto. Para tanto, afirma que, se a fabricante da cerveja "fabricasse" a "Musa do Verão", uma moça atraente vestindo um biquíni, essa seria distribuída a qualquer homem que se interessasse. Com isso, cria a ideia de que a mulher em questão é um bem a ser produzido em série e livremente consumido pelos homens. Coisificando a mulher, a peça

\footnotetext{
${ }^{8}$ Disponível em: < http://www.migalhas.com.br/arquivos/2016/6/art20160620-03.pdf>. Acesso em 19 jul. 2016. P. 09.
} 
discrimina, separa, aparta os gêneros, tratando o sexo masculino como o consumidor e o feminino como o bem a ser consumido, que deve ser perfeito (a propaganda faz alusão a um exemplar da "Musa" que teria "vindo com defeito") para satisfazer aos desejos dos consumidores".

O revisor também salienta as mudanças sociais pelas quais perpassamos, citando como exemplo as campanhas feministas realizadas em redes sociais, como \#meuprimeiroassedio e \#meuamigosecreto ${ }^{10}$. Ademais, argumenta que a liberdade de expressão nos casos relativos ao direito consumerista é menos ampla, pois o consumidor aparece como sujeito vulnerável, já que não escolhe onde ou quando irá assistir propagandas, sendo mais influenciável.

Dessa forma, percebe-se como os relatórios oferecidos são decisões estritamente jurídicas e vinculadas aos Direitos Humanos. Ambos os relatórios, ainda, estão de acordo com a Quarta Conferência Mundial das Nações Unidas sobre as Mulheres e a Igualdade de Gênero, de 1995. Tendo por principal pauta o desenvolvimento da mulher, estabeleceu-se a necessidade de erradicação das desigualdades de gênero, em todas as suas formas, bem como de erradicação dos tratamentos estereotipados de gênero nos meios de comunicação (NAÇÕES UNIDAS, 1995).

Neste ponto, é preciso fazer uma observação: é certo que a publicidade pode influenciar no desejo final do consumidor, mas também é preciso destruir o mito de que o espectador é um sujeito passivo, que tal qual uma esponja absorve e internaliza toda e qualquer mensagem que lhe é transmitida. Como mencionado anteriormente, ao realizar experimento de natureza empírica, Adorno, um dos grandes críticos da Indústria Cultural conclui que a audiência não era tão passiva quanto ele próprio supunha.

Posição similar tem Kellner (2001, p. 90), para quem o público é uma esfinge: é impossível prever, a priori, os impactos que determinados discursos midiáticos causarão no telespectador, justamente porque este é um sujeito difuso dotado de subjetividade e vivência singular. É possível que as mensagens sejam absorvidas de maneira distinta da qual pretendia o emissor, ou que sejam ressignificadas. Não por acaso, um dos maiores desafios dos pesquisadores que se propõe a utilizar mídias como fontes (músicas, filmes, seriados, revistas, dentre muitos outros), está na recepção e impacto da obra perante o público.

Contudo, o que se está a salientar é a decisão que condena a mensagem veiculada midiaticamente, capaz de criar e perpetuar papéis sociais estereotipados, não a forma como cada um dos espectadores entenderá a mensagem. O que importa é a forma como a comunicação expressa uma determinada mensagem, independentemente de ela gerar desconforto em todos os espectadores ou não.

Compreendidos estes aspectos no que se refere à mídia, apresentamos o voto divergente do juiz

\footnotetext{
${ }^{9}$ Disponível em: < http://www.migalhas.com.br/arquivos/2016/6/art20160620-03.pdf>. Acesso em 19 jul. 2016. P. 19.

${ }^{10}$ As duas hashtags, \#meuprimeiroassedio e \#meuamigosecreto, foram utilizadas em redes sociais para denunciar casos de assédio contra mulheres. Maiores informações em: <http://migre.me/v5sLf> e <http://migre.me/v5sLQ>. Acesso em 27 set. 2016.
} 
Coimbra Schmit, que permaneceu como voto vencido. Para ele, a peça publicitária apareceu como mero entretenimento cômico, divertido, sem maiores ofensas à dignidade da mulher:

Nem por isso, data venia, seu julgamento deve dissociar-se da realidade: é fato que, nas praias, os trajes femininos são cada vez mais sumários. É fato ser o ideal da musa componente do imaginário masculino e isso desde tempos bem antigos. O que fez o comercial sob julgamento? Transpôs ao mundo da publicidade essa realidade de nossos balneários ao onírico do público destinatário da mensagem, em filme de grande impacto por sua originalidade, irradiada da intensa dose de criatividade com que se houveram seus autores. Publicitários que bem souberam sintetizar esses fatores em peça recheada pelo BOM humor característico da picardia do brasileiro associado à alegria imanente a reuniōes em cervejarias: in vino veritas., in cerivisia felicitas! $\mathrm{E}$ o que se faz ao punir o anunciante com pesada multa é, justamente, cercear essa criatividade, inerente à liberdade de expressão garantia fundamental consagrada na Constituição - mediante ato de censura econômica, apenas porque alguns viram a ousadia como ofensa à condição feminina. Definitivamente, não foi essa minha leitura. [...] E vou além: acatar a tese defendida pela apelante significa ferir de morte a publicidade brasileira, instigando seus agentes a ousar apenas em cenários neutros, com locutores trajados formalmente e textos cuidadosamente revistos a fim de que suscetibilidade alguma possa vir a ser ferida, sob pena de pesadas sanções. Claro cenário de materialização da pior das censuras: a autocensura! ${ }^{11}$

Apesar do mencionado voto e das argumentações realizadas acerca da possível receptividade do telespectador, é necessário considerar que as veiculações midiáticas nunca são inocentes ou neutras: como fruto da ação humana, as obras carregam tanto parte da subjetividade de seu autor, como elementos representativos do contexto social e histórico nos quais foi produzido. Enquanto produtos culturais, as mídias, inclusive as propagandas, buscam transmitir mensagens por meio da comunicação - da linguagem. A subjetividade é inerente a estes trabalhos.

Porém, também não se pode incorrer na falácia de que os textos midiáticos são intrinsicamente positivos ou negativos, opressores ou libertadores. Para Kellner,

os textos culturais não são intrinsecamente 'conservadores' ou 'liberais'. Ao contrário, muitos textos tentam enveredar por ambas as vias para cativar o maior público possível, enquanto outros difundem posições ideológicas, estratégias narrativas, construção de imagens e efeitos (por exemplo, cinematográficos, televisivos, musicais) que raramente se integram numa posição ideológica pura e coerente. Tentam oferecer algo a todos, atrair o maior público possível e, por isso, muitas vezes incorporam um amplo espectro de posições ideológicas. Além disso [...], certos textos dessa cultura propõe pontos de vista ideológicos específicos que podemos verificar estabelecendo uma relação deles com os discursos e debates políticos de sua época, com outras produções culturais referentes a temas semelhantes e com motivos ideológicos que, presentes na cultura, estejam em ação em determinado texto (2001, p. 123).

Em outras palavras, a mídia é alimentada pelo lucro. Se a propaganda da cerveja Skol foi veiculada em rede nacional com todas essas características depreciativas ao feminino, não se trata da ação isolada de um publicitário, mas de um contexto social no qual propagandas deste tipo fazem sucesso e geram algum retorno. A reação negativa por parte de alguns setores sociais que permitiram o questionamento da propaganda em juízo é um sintoma promissor de que existem mudanças e rupturas em andamento, que não mais aceitarão ou 
consumirão este tipo de discurso.

O relatório do juiz Schmit, nesse sentido, que afirma a necessidade de reconhecimento do bom humor no merchandising, é contrário à necessidade internacional de erradicação com as práticas discriminatórias, inclusive televisivas ou midiáticas, que reproduzem estereótipos nocivos à questão de gênero. Não se trata, assim, de uma decisão de cunho moral ou contrária à criatividade ou à liberdade de expressão, mas uma decisão protetora da dignidade humana e dos Direitos Humanos, inclusive ratificados pelo Brasil e constitucionalizados. A própria liberdade de expressão não é absoluta, devendo respeitar a dignidade humana.

Diante dessas considerações, outra questão se insurge: diante de casos como estes, nos quais há uma ofensa concreta à dignidade humana, qual seria o papel do judiciário? Está o judiciário apenas decidindo questões morais ou, mais do que isso, questões jurídicas atinentes aos Direitos Humanos e direitos fundamentais? Até esse momento, parece bastante acertado afirmar que o judiciário, nestes casos, não atua como guardião da moralidade, mas antes, como guardião de direitos constitucionalizados, como os Direitos Humanos, em prol da dignidade de todos, inclusive das mulheres.

\section{O PODER JUDICIÁRIO, A DIGNIDADE E A MORALIDADE}

O questionamento proferido pelo juiz Schmit em seu voto divergente, sobre a vedação de determinados discursos por parte do Judiciário, não poderia acabar incorrendo em censura? Afinal, o que seria exatamente, uma propaganda abusiva? Quem determinaria tais parâmetros? Mais do que isso, estaria o Judiciário, no caso em análise, decidindo sobre questões morais ou jurídicas?

Para Waldron (2009), existe uma crença compartilhada segundo a qual o raciocínio moral dos juízes em relação a questões controversas seria melhor do que o raciocínio do poder legislativo. Assim, este seria o motivo pelo qual os juízes deveriam ser a autoridade final no que se refere à questão de direitos individuais e de minorias. Essa afirmação baseia-se no dogma já cristalizado segundo o qual os juízes não sofrem pressões internas quando atuam na seara decisória, enquanto o legislativo sofre pressões de forma que tratem as questões delicadas de uma forma não confiável.

Por outro lado, segundo Waldron (2009), a Suprema Corte, e mesmo o Judiciário em geral, convence quando apresenta seus raciocínios - sabem utilizar argumentação. Assim, aparentemente, tratam questões de princípios como questões de princípios e não como questões de ordem financeira, ou de forma populista para angariar votos, como o parlamento.

Conforme Waldron (2009), quando um magistrado emite sua decisão, ele evoca a letra da lei, mas ele não abdica de um raciocínio moral quando assim faz. Todavia, a crença de que os juízes são mais aptos a

\footnotetext{
${ }^{11}$ Disponível em: < http://www.migalhas.com.br/arquivos/2016/6/art20160620-03.pdf>. Acesso em 19 jul. 2016. P. 27-28.
} vol.10, nº. 04, Rio de Janeiro, 2017.pp. 2570-2584 
decidirem moralmente, utiliza apenas padrões morais para avaliar a qualidade dos raciocínios judiciais, motivo pelo qual suas conclusões não são confiáveis. Essa crença ignora que o juiz também precisa buscar a norma. Neste sentido, é preciso ter em mente que os juízes precisam obedecer a uma série de doutrinas, precedentes, textos e interpretações com os quais a justificativa legal necessariamente se preocupa e que inevitavelmente compromete as justificativas morais das Cortes (WALDRON, 2009).

Ainda assim, Waldron afirma (2009) que alguns autores defendem que seria melhor que o juiz fundamentasse sua decisão conforme sua própria moral individual, no intuito de evitar absurdos como em um caso relativo à fuga de um escravo, no qual o juiz admitiu que, como cidadão, considerava a lei injusta, mas como jurista era necessário aplicá-la.

Esse pensamento, porém, parte do falso princípio de que a moral é una. Ao escrever sua Teoria Pura do Direito, Kelsen já alertava para o grande problema em se confundir direito e moral:

Em vista [...] da grande diversidade daquilo que os homens efetivamente consideram como bom e mau, justo e injusto, em diferentes épocas e nos diferentes lugares, não se pode determinar qualquer elemento comum aos conteúdos das diferentes ordens morais. Tem-se afirmado que uma exigência comum a todos os sistemas de Moral seria: conservar a paz, não exercer violência sobre ninguém. Mas já Heráclito ensinou que a guerra não só é o "pai”, isto é, a origem de tudo, mas também o "rei", isto é, a mais alta autoridade normativa, o mais alto valor, sendo, portanto, boa, que o Direito é luta e que a luta, por isso, é justa. E até Jesus diz: "Eu não vim para trazer a paz à terra, mas a discórdia" e, portanto, não proclama de forma alguma, pelo menos para a ordem moral deste mundo, a paz como o valor mais alto. Poderá negar-se que também hoje, segundo a convicção de muitos, a guerra tem valor moral porque possibilita a comprovação das virtudes, a realização de idéias que se colocam em plano mais alçado que os valores da paz? Ou é porventura a moral do pacifismo uma moral indiscutida? Corresponde a filosofia da vida do liberalismo segundo a qual a competição, a luta da concorrência, garantem a melhor situação possível da sociedade, ao ideal da paz? Este não representa de forma alguma para todos os sistemas de Moral o valor mais elevado, e para muitos nem sequer representa qualquer valor. [...] O que é comum a todos os sistemas morais possíveis é a sua forma, o dever-ser, o caráter de norma. É moralmente bom o que corresponde a uma norma social que estatui uma determinada conduta humana; é moralmente mau o que contraria uma tal norma. O valor moral relativo é constituído por uma norma social que estabelece um determinado comportamento humano como devido (devendo-ser) (KELSEN, 1999, p. 46).

Percebe-se, portanto, que os valores morais são elementos diversos e subjetivos, de forma que diversos parâmetros morais coexistem em âmbito social e, por consequência, jurídico. 
Contudo, a análise efetuada na seção anterior parece concluir que, no caso analisado, não ouve uma decisão moral por parte do juiz relator e revisor, mas antes, uma decisão fundamentada em critérios de diminuição da desigualdade de gênero e redução de concepções estereotipadas no gênero feminino, estando em consonância com as normativas internacionais de Direitos Humanos, as quais foram ratificadas pelo Brasil e constitucionalizadas.

Se, por um lado, a condenação da Ambev pelo Tribunal de São Paulo aparentemente representa um discurso progressista e emancipador no que se refere à dignidade feminina, é importante mencionar outro caso, também envolvendo a questão feminina, mas julgado por um juiz de primeira instância em Vitória/ES.

Em resumo, três mulheres ajuizaram ação contra a Cervejaria Devassa, a Schincariol, o jornal A Gazeta, uma empresa de logística e uma agência de comunicação. O motivo da ação foi a propaganda aparentemente preconceituosa e estereotipada reproduzida abaixo:

\section{Figura 01 - Propaganda da Cerveja Devassa}

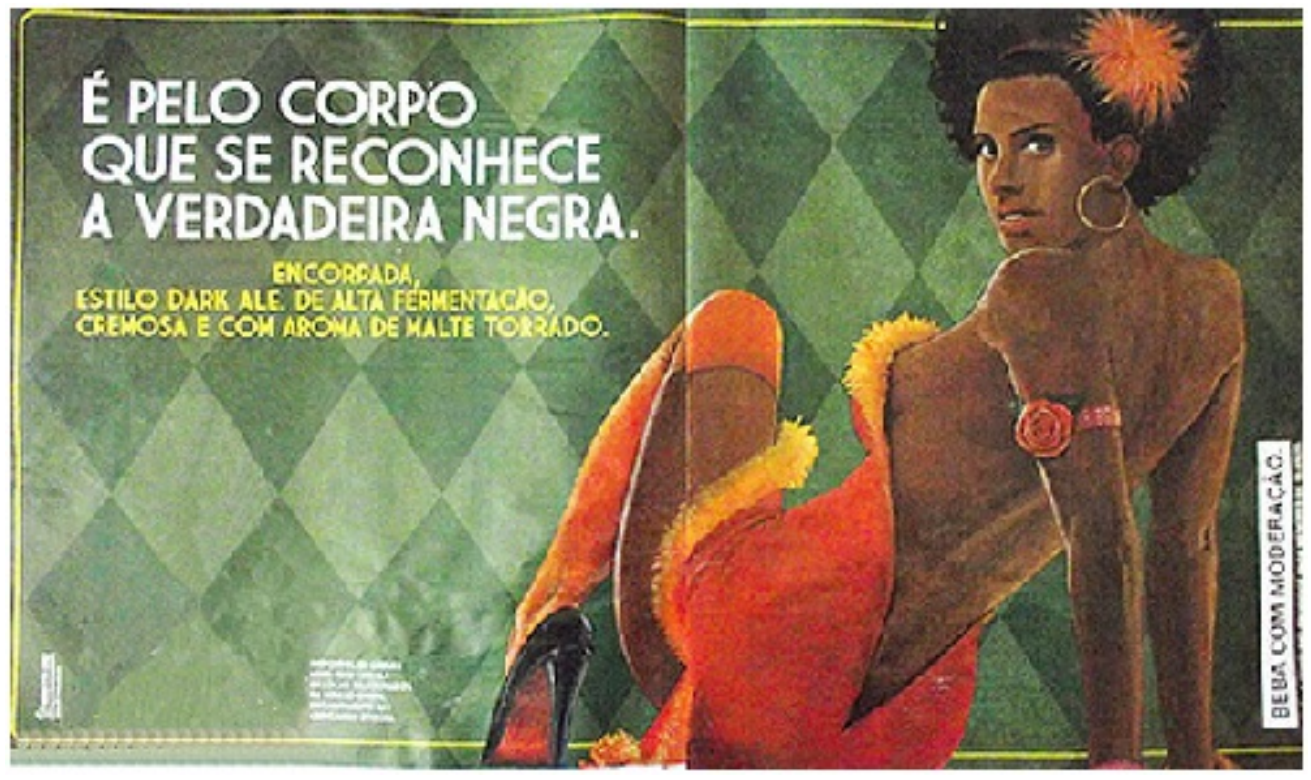

Fonte: < http://migre.me/v5tfW>. Acesso em 27 set. 2016.

As alegações das autoras, baseando-se em argumentos contrários ao preconceito racial e feminino, segundo o relatório da sentença, são as seguintes:

A primeira Autora foi ao Procon Municipal de Vitória, onde fez uma reclamação administrativa e também à delegacia de defesa do consumidor. O Procon notificou e autuou a Cervejaria Devassa, originando infração administrativa. Que a segunda Autora foi submetida à discriminação negativa, uma vez que é professora e leitora do jornal A Gazeta, se deparando com a publicidade da Cervejaria Devassa, cujo teor da propaganda é racista e prejudicial à imagem não só da mulher negra como objeto sexual, imagem esta construída ao longo da história do Brasil. Que foi a Delegacia de Defesa do Consumidor, ao Ministério Público e à Ordem dos Advogados do Brasil. Que a terceira Requerida igualmente teve seu direito a diferença atingido devido à discriminação negativa, sentindo-se ofendida, 
constrangida, uma vez que também é mulher e negra. Que anda pela rua e fica ouvindo transeuntes do sexo masculino que dizem: "ESSA É A VERDADEIRA DEVASSA", "QUE DÁ VONTADE DE BEBER”. Que desta maneira está sendo reforçada a ideia de que as mulheres negras são consideradas um objeto sexual, devido a propaganda racista e machista de cunho sexual. Que as autoras estão sofrendo constrangimento e humilhação ${ }^{12}$.

Em sede de contestação, alguns argumentos merecem ser destacados:

A primeira Requerida, PRIMO SCHINCARIOL IND DE CERVEJAS E REFRIGERANTES S/A, apresentou contestação às fls. 166/182, alegando [...] que a propaganda atacada não tem mínimo potencial ofensivo e, ainda que entendam o contrário, os anúncios não causam à média da população qualquer desconforto ou desequilíbrio emocional e espiritual. Registra que as três Autoras estão diretamente envolvidas com políticas de promoção de igualdade racial e causas voltadas a defesa da população afrodescendentes, o que explica a suscetibilidade exacerbada que transmitem diante da propaganda. Que não discrimina qualquer cor ou raça, ao contrário, rende homenagens a todos os fenótipos através de suas cervejas. Que o anúncio atacado pelas Autoras apenas dá sequencia a esta mesma linha irreverente da campanha publicitária da marca Devassa, o que explica a roupa da mulher nele inserida, não se tratando, portanto, de criação destinada a atingir a mulher negra.

A quarta Requerida, AGENCIA MOOD DE COMUNICAÇÃO INTEGRADA LTDA., em contestação de fls. 327/342, [...] alegou [...] que não agiu com culpa muito menos com dolo, na medida em que jamais tencionou agredir ou depreciar a figura da mulher negra. Que não houve qualquer tipo de discriminação racial na publicidade da cerveja Devassa e que sempre se utilizou da publicidade comparativa com a figura feminina com o objetivo de divulgar a marca, ressaltando as características mais marcantes das mulheres brasileiras, para associa-las às suas diversas cervejas.

Cabe aqui resgatar a ideia de Kellner de que o público midiático possui reações distintas a mensagens e discursos diferenciados. $\mathrm{O}$ fato das autoras da ação estarem engajadas com políticas de promoção de igualdade racial obviamente interfere nas suas interpretações da propaganda veiculada; mas o fato do tipo de comercial ser corriqueiro e socialmente aceito não o torna imune a críticas a problematizações, pois a sua produção e veiculação também contém a subjetividade, os valores e a vivência de quem o idealizou. O debate é mais profundo e complexo do que os autos deixam transparecer.

Contudo, há que se ter em mente que a imagem de merchandising não apresenta a figura de uma cerveja, mas de uma mulher negra, com vestido extremamente decotado e em pose sexualizada e estilo pinup girl. Escrito em letras grandes, aparece a frase: 'É pelo corpo que se reconhece a verdadeira negra”. E apenas em letras pequenas, escrito: "Encorpada, Estilo dark ale de alta fermentação, cremosa e com aroma de malte torrado”.

Se for certo considerar que toda a mídia é uma forma de comunicação pela linguagem, composta de signo, significante e significado, parece bastante óbvio que a propaganda analisada, quando escreveu em grandes letras "É pelo corpo que se reconhece a verdadeira negra" buscou transmitir uma mensagem sexualizada da imagem da mulher ao lado. Caso contrário, ter-se-ia utilizado a imagem de uma cerveja. Sexo vende. Daí porque apenas em pequenas letras se faz alusão à cerveja "Encorpada, Estilo dark ale de alta fermentação, cremosa e com

\footnotetext{
${ }^{12}$ Disponível em: <http://migre.me/v5qmN>. Acesso em 27 set. 2016.
} 
aroma de malte torrado".

Trata-se de uma propaganda estereotipada da mulher negra, reprodutora de sexualização e papéis sociais. Contudo, esse não foi o entendimento do juiz que decidiu o caso. No interesse, nesse sentido, o argumento moral utilizado pelo juiz para decidir a causa em questão:

Analisando os autos, e a propaganda juntada às fls. 45, o que se percebe é a utilização da propaganda de uma forma criativa, associando a beleza, as vestes reduzidas, o bom humor, a alegria ao consumo da cerveja, o que é muito comum no nosso país. É notório que no Brasil as propagandas de cerveja são conhecidas pela sua originalidade e criatividade, ainda que possam ser consideradas jocosas. No caso em análise não se percebe nenhuma mácula na imagem da mulher negra. Pelo contrário, a propaganda realmente é irreverente e a ideia é causar um impacto com humor com o objetivo, certamente, de provocar comentário, chamar a atenção do consumidor. Se alguma conclusão pode ser tirada a respeito, é exatamente o elogio ao corpo da mulher. Ora, conforme bem apontado pela primeira Requerida, muitas vezes que se tem a pele negra figurando em publicidade, surgem questionamentos associando a mídia à vulgaridade, a inferioridade, discriminação racial. É preciso muita cautela nesses questionamentos para não banalizar as verdadeiras reinvindicações. [...] a propaganda não é abusiva ou discriminatória. Não há qualquer mensagem racista, sendo o anúncio original, irreverente, refletindo uma essencialidade, autenticidade e alegria ${ }^{13}$.

O juiz entendeu que a propaganda é original e criativa, mas elogiosa ao corpo da mulher e da pele negra.

Apesar da decisão, levanta-se a questão da dignidade da mulher, trazida na seção anterior.

Mais ainda, considerando a Convenção sobre a eliminação de todas as formas de discriminação racial (1969), adotada pelas Nações Unidas na resolução 2.106-A (XX), em 1965, ratificada pelo Brasil e constitucionalizada; e, tendo em mente que a nomenclatura discriminação racial significa qualquer distinção, exclusão, restrição ou preferência baseada na raça, cor, descendência, origem nacional ou étnica, com o propósito ou o efeito de anular ou restringir o reconhecimento, gozo ou exercício, em condições de igualdade, dos direitos humanos e das liberdades fundamentais no campo político, econômico, social, cultural ou em qualquer outro domínio da vida pública; parece que a propaganda é discriminatória racialmente e, ainda, conforme análise na seção anterior, na questão de gênero.

Considerando todas as formas de apartheid, segregação e discriminação sofridas pela população negra, e, ainda, considerando as discriminações, violências e anulações da população feminina, uma propaganda com tal teor, de que se conhece a mulher negra pelo seu corpo, é moralmente preocupante e, mais do que isso, contrária ao conhecimento dos Direitos Humanos. Não é pelo corpo que se conhece a mulher. É pela sua representatividade social.

Contudo, percebe-se que, em casos similares (propagandas de cerveja que teriam ofendido a dignidade feminina), o judiciário oferece respostas diferentes. Se por um lado a Ambev não pode veicular propagandas nas quais a mulher é vista como mercadoria, a Schincariol pode utilizar a figura da mulher negra de forma irreverentee

\footnotetext{
${ }^{13}$ Disponível em: <http://migre.me/v5qmN>. Acesso em 27 set. 2016.
} 
criativa, pois se trata de um elogio e não uma ofensa. Neste sentido, pode-se questionar o papel dos juízes em questões polêmicas relacionadas à moralidade: eles realmente seriam as melhores escolhas para cuidar de casos tão delicados e complexos?

Diante dos casos analisados, entende-se que não. Os juízes não devem decidir questões polêmicas concernentes à moralidade, mas devem responder e decidir sobre questões jurídicas relativas à dignidade e aos Direitos Humanos, a partir da Constituição Federal e leis infraconstitucionais.

Se o Poder Judiciário não pode decidir sobre todas as mídias veiculadas diariamente, por outro lado, pode decidir sobre aqueles casos que the são levados à apreciação jurídica.

A moral não é una, conforme analisado. Segundo a moral individual, uma propaganda por ser jocosa, divertida ou preconceituosa. Contudo, o Direito brasileiro é uno. Um sistema de normas aptas a serem interpretadas e aplicadas nos casos concretos. Principalmente nos casos que envolvem a dignidade, são as leis e direitos que devem permear as decisões: a interpretação e aplicação de normativas de direitos humanos e dos direitos fundamentais constitucionalizados, não a moral social ou individual.

Coibir a comunicação estereotipada, discriminatória e preconceituosa parece ser o papel central hoje em dia para a modificação de papeis sociais nocivos e reprodutores de violência.

\section{CONSIDERAÇÕES FINAIS}

A crença de que os juízes teriam habilidades superiores para tratar de questões relativas à moralidade raramente é questionada. Exemplo disso é o fato de que os jurisdicionados não medem esforços para invocar a atuação estatal nos mais diversos casos, como nos exemplos relativos às propagandas de cerveja.

O que deve ser salientado, desde já, é que os casos analisados se referem à moralidade, mas antes, à dignidade humana - o caso da sexualização da mulher e o caso da sexualização em função racial. Para além de simples argumentos morais, os casos destacados neste artigo problematizam questões de Direitos Humanos e da dignidade, considerando-se a vedação de distinções, preconceitos e desigualdades fundadas no gênero e na cor da pele.

O principal problema neste tipo de caso é o comportamento do magistrado, que tende a decidir as demandas não com base em um contexto político e jurídico possível, procurando adequar-se as alternativas viáveis, mas sim levando em consideração a sua própria moral subjetiva. Neste ponto, Waldron afirma ser necessário não levar em consideração apenas a moral individual do julgador, mas buscar todo o aparato de precedentes para dentro dos limites da legislação achar a decisão e fundamentação mais adequada ao problema a ser resolvido, não como Eu faria isso se fosse o dono do mundo, mas sim como Eu acredito que dentre as opções disponíveis isso é o melhor a fazer (WALDRON, 2009, p. 17). 
Por outro lado, se pensarmos a mídia como um cenário de disputas por lucro, pode-se questionar até que ponto o judiciário seria a via mais adequada para se impedir a veiculação de determinados discursos. Em casos envolvendo ofensas a partir de meios de comunicação, boicotes, manifestações e cartas de repúdio contra as empresas, a partir do próprio público consumidor, não seria uma forma mais eficaz de demonstrar o descontentamento e a necessidade de novas propagandas, novas músicas, novos filmes, nos quais a mulher finalmente se libertaria de atributos impostos desde tempos antigos?

Não há - e nem deveria haver - uma resposta fácil. Mas o que urge para o momento é repensar o dogma muitas vezes sustentado pelos próprios jurisdicionados de que os juízes são os melhores guardiões da moral.

\title{
MEDIA AND COURT: CONSIDERATIONS CONCERNING DEVELOPMENT, MORALITY, DIGNITY AND THE JUDGES FROM BEER ADVERTISEMENTS
}

\begin{abstract}
The theme of this essay is the Media, the Judges, dignity and the morality, and it seeks to establish the need to rethink the role of judges as moral guardians of legal and social demands. Starting by Jeremy Waldron's criticized dogma, that the judges would be the most suitable individuals to solve morally controversial issues, we turn to two court decisions concerning similar cases: beer commercials with offensive potential to female dignity. The main objective is to analyze the problems involved in the dogma. In order to do so, methodologically, we will investigate the roll of Media and its language, and later on, analyze the idea that the judged are more suitable to solve legal and social issues concerning morality. In the end, we question the problem of mixing individual morality in legal issues concerning human rights.
\end{abstract}

Keywords: Law; Media; Judges; Morality; Female Dignity.

\section{REFERENCIAS}

ADORNO, Theodor W. Tempo Livre. In.: ALMEIDA, Jorge M. B. de (org). Indústria Cultural e Sociedade: Theodor Adorno. São Paulo: Paz e Terra, 2002.

ADORNO, Theodor W.; HORKHEIMER, Max. A Indústria Cultural: O Esclarecimento como mistificação das massas. In.: ADORNO, Theodor; Max. Dialética do Esclarecimento: fragmentos filosóficos. Rio de Janeiro: Jorge Zahar, 1985.

BENJAMIN, Walter. A obra de arte na era de sua reprodutibilidade técnica. In.: Magia e técnica, arte e política: Ensaios sobre literatura e história da cultura. Obras Escolhidas - Volume I. São Paulo: Brasiliense, 1987.

GRUBBA, Leilane Serratine. Conquistas jurídicas ou práticas sociais: quê são direitos humanos?. In.: Thesis Juris, v. 4, 2015. p. 339-356. 
KELLNER, Douglas. A cultura da Mídia: estudos culturais, identidade e política entre o moderno e o pósmoderno. Bauru, SP: EDUSC, 2001.

KELSEN, Hans. Teoria Pura do Direito. São Paulo: Martins Fontes, 1999.

LEAL, César Barros. Les droits de l'homme et le respect à la dignité de la personne dans le contexte des príncipes de la justice restaurative. In.: CANÇADO TRINDADE, Antônio Augusto; LEAL, César Barros (coord). Le respect de la dignité humaine. IV Cours Brésilien Interdisciplinaire em Droits de l'Homme. Fortaleza: IBDH, 2015.

NAPOLITANO, Marcos. História e Música: história cultural da música popular. Belo Horizonte: Autêntica, 2005.

NAÇÕES UNIDAS. International convention on the elimination of all forms of racial discrimination. 1969. Disponível em: <http://www.ohchr.org/EN/ProfessionalInterest/Pages/CERD.aspx>. Acesso em 4 de dezembro de 2013.

Convention of the elimination of all forms of discrimination against women. 1979. Disponível em: <http://www.ohchr.org/EN/ProfessionalInterest/Pages/CEDAW.aspx>. Acesso em 13 de janeiro de 2014.

Fourth world conference on women. 1995. Disponível em: <http://www.un.org/womenwatch/daw/beijing/fwcwn.html>. Acesso em 4 de dezembro de 2013.

SALIBA, Elias Thomé. As imagens canônicas e a história. In.: CAPELATO, Maria Helena; [et. al.]. Historia e cinema. São Paulo: Alameda, 2007.

WALDRON, Jeremy. Judges as moral reasoners. International Journal of Constitutional Law, Volume 7, $\mathrm{n}^{\circ} 1$, 2009.

Trabalho enviado em 28 de março de 2017.

Aceito em 04 de julho de 2017. 